SZELENYi, IVAN

ivan.szelenyi@yale.edu

professor (Yale University, NYUAD, USA)

\title{
Pathways from and Crises after Communism
}

Part 2. The Case of Former USSR and China

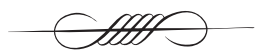

For the first part of this paper see Belvedere Meridionale 2014. vol. 26. no. 4.

Abstract The transition from socialist redistributive economy to capitalist markets has proved to be a rockier road that anticipated. The degree and character of difficulties that the countries faced during the transition depended on the nature of the pathways taken.

In this paper I distinguish three major trajectories various countries followed: Central European neo-liberalism; post USSR neo-patrimonial regime and the East Asian (Chinese and Vietnamese) transformation from below. Rather than distinguishing the "right way" from the "wrong way" I explore what the different costs and benefits of the various pathways were at various stages of the transformation.

Keywords neo-patrimonial regimes, regimes, transformation, USSR, China

DOI 10.14232/belv.2015.1.1 http://dx.doi.org/10.14232/belv.2015.1.1

Cikkre való hivatkozás / How to cite this article:

Szelenyi, Ivan (2015): Pathways from and Crises after Communism. Part 2. The Case of Former USSR and China. Belvedere Meridionale vol. 27. no. 1. 5-26. pp

ISSN 1419-0222 (print) ISSN 2064-5929 (online, pdf) 


\section{Neo-patrimonial regimes}

I call the second trajectory neo-patrimonial and - with the exception of the Baltic States which followed the prescriptions close to neo-liberalism - the countries of the former USSR can arguably be classified as such. The purest type of this pathway is the Russian one. (i) The emergent political system is "managed democracy" (typically referred to as "presidential Republic"). Political power is usually held by people who were closely associated with former communist rule. They were elected to office, but their electoral success was "managed", the ancient regime was organically transformed rather than radically broken up in order to reduce the dangers of instability. (ii) The post-communist rulers and the rule itself are paternalistic. The privatization process was as fast (or even faster) as under the neo-liberal model, but it did not follow the "blind forces" of market, it was resistant to invasion by multinational capital and rewarded clients (often called "oligarchs") who promise to be competent and loyal with property. (iii) The paternalistic logic applies to management-worker relationship as well: employers rather than laying workers off did not pay their wages, instead they offered them provisions in kind (barter - at least initially - was often extensive). How well or poorly neo-patrimonial regimes performed is contested. They might have absorbed the initial shock of transition better than neoliberal regimes (especially as far as relatively moderate reduction of labour force participation is concerned), but the subsequent disintegration of the economy and social order was even deeper and lasted even longer. Nevertheless, those who were ready to deliver the verdict by 2000 would have arrived at a conclusion prematurely. The second decade of the transition turned out to be rather successful for the neo-patrimonial pathway, Russia and the Central Asian Republics took off. While in 2008-09 neo-patrimonial regimes also took a dive, they fast recovered and they seem to be less vulnerable by the euro crisis. It remains to be seen whether this is a sustainable growth trajectory or merely a one-time return on oil and mineral wealth. Some analyst suggested that Russia undertook at least a partial re-industrialization following the financial collapse of 1998 as a response of the sharp drops of domestic demand to import-products. In what follows I offer data from to so calls FSU-5, the five population-wise largest post-Soviet states (Belarus, Kazakhstan, Russia, Ukraine, Turkmenistan)

\section{The first phase of neo-patrimonial transition (1989-1998): deeper and prolonged recession}

The USSR broke up in December 1991, but the writing was on the wall before: some countries declared independence and the economies were already declining by 1989-1990. The following decade was an unmitigated disaster. The GDP fell by some $50 \%$, life expectancy declined substantially (mortality of middle aged men skyrocketed). I could not find systematic data on poverty/living standards, but by all indication it went through the roof. In my 2000 survey (KLIGMAN - SzELENYi 2002.) I asked randomly selected respondents on a large sample to report poverty in 2000 and recall whether they experienced the same level of poverty in 1988. In 2000, 17\% of our Russian respondents were below \$2.15 PPP expenditure level (the same figure in Hungary was $1.8 \%$; in Poland $1.7 \%$ ). While Russia was a poorer country than its CEE satellites by the end of socialism (what in irony of Soviet imperialism), it became much-much poorer after ten years of transition. Since the trend of decline in GDP and life expectancy is similar in the other four neo-patrimonial countries, there is good reason to believe that their speed (and level) of impoverishment is comparable to Russia.

Furthermore, the recession was not only deeper in neo-patrimonial regimes (and they without doubt qualify for the D word: “depression") but is also lasted longer. While neo-liberal 
countries generally recovered by the year 2000 and were at or near the 1988 levels states on neo-patrimonial trajectory generally were still in free fall as late as 1998 . Recovery had to wait until the middle of the first decade of the $21^{\text {st }}$ century.

But in other indicators the neo-patrimonial regimes did not do that poorly. These countries managed sharp falls in GDP with relatively small unemployment and quite substantial labour force participation. Take the case of Russia. This country in 1992 was in decline for the third consecutive year and just in that single year the GDP fell by $15 \%$ - nevertheless unemployment stood only at $5 \%$ and labour force participation was still at a respectable $66 \%$. Or Ukraine: by 1995 the Ukrainian GDP was down by some 50\%, but unemployment did not reach $6 \%$ yet!

There is some debate about what caused the disaster of the first decade of the transition and much research remains to be done to give a persuasive answer to this question. Some (SACHS 2005.; AsLund 1995, 2007.; AsLund - GuRIEV - KuCHIns 2010.) blame initial conditions and lack of consistency in the reforms (and these authors tend to emphasize the relative success of the transition), others (STIGLITZ 2003.; KING 2003.) blame the reform strategy, "shock therapy", especially mass or voucher privatization (and tend to see the Russian way to capitalism as a disaster).

The Russian (and Ukrainian) neo-patrimonial order seems to be related both to the rather dramatic decline in the economy and the relative moderation in unemployment and decline in labour force participation. Hence it had its "upside" and "downside" even during the first decade. The unique feature of privatization under neo-patrimonial order was the exceptionally fast transfer of public property into private hands of a new small elite almost "handpicked" by the patrimonial rulers. "We need millions of owners, rather than a handful of millionaires... The privatization voucher is a ticket for each of us to a free economy" - said President Boris Yeltsin, ${ }^{1}$ but this had opposite effect. Given the speed the political leadership intended to transform property rights (to make capitalism "in 500 days") it led to the emergence of an oligarchy. How and why? Arguably voucher privatization was intended to achieve sort of Proudhonian socialist aims. Indeed: who not make everyone an owner by distributing the common wealth to all citizens or at least to all workers of a given firm? Future vice premier, Chubais was responsible for privatization and under his watch privatization vouchers were mailed out to every Russian citizen. But most of them did not know what to do with them, but since their savings disappeared due to hyper-inflation, they offered their vouchers virtually at any price for sale in the emergent secondary market for vouchers. A small group of entrepreneurs and entrepreneurially minded managerial personnel bought up the vouchers and privatized state owned enterprises well below their value. Klebnikov for instance estimated that Gazprom which sold for \$250 million in 1994 by 1997 it was worth $\$ 40$ billion $^{2}$. Instantly a new class of a few dozen (or at best few hundred, certainly not millions) dollar billionaire oligarchs emerged.

The oligarchs of neo-patrimonial post-communism were similar in many ways to the robber barons in $19^{\text {th }}$-century America. And as Aslund among others pointed out there is nothing wrong about making such a class, if that solves the property problem (helps to create identifiable owners), what it certainly did. But there were some important differences between the oligarchs of neo-patrimonial order and the robber barons of the Wild-West US capitalism. For better or worse the robber barons were certainly not clients of the American political class, on the con-

\footnotetext{
1 Cited by Aslund 1995. 235.
}

2 KlebNikov 2000. 135. 
trary, already during the late $19^{\text {th }}$ century money called the shots. Under neo-patrimonial order the new rich were sort of "appointed" by the political rulers (and if they proved to be disloyal or unpredictable, like Berezovsky or Khodorkovsky from Putin's point of view they were "fired" or jailed). Even more importantly, while almost all American robber barons made their millions by MAKING something (producing steel like Carnegie, drilling and refining oil like Rockefeller, building railways - no matter how useless some of those were - like Gould, who resembles most the Russian "oligarchs" who built railway line, even though some of those only bought markets along already existing lines - they created wealth. In sharp contrast the oligarchs at least under the first decade of market transition under neo-patrimonial regimes made billions from speculation (like Berezovsky purchasing cars from state owned firms at subsidized price promising hard currency revenues, but immediately re-exporting them in Russia for high profits on car markets where consumers normally had to wait for years for Russian cars, but could drive off from the saloons of Berezovsky immediately by paying higher than usual prices). So the US economy was booming with the raise of robber barons, the Russian economy was collapsing as the oligarchs were transferring their extra profits from privatization speculations to Swiss bank accounts (this is what Berezovsky also did, since the purchased cars from AVTOVAZ with promissory notes when inflation rate was $1000 \%$ in Russia, so "saved" his profit in stable Swiss Franks) and freezing them into mansions on the Riviera, Colorado Springs or you name it where.

Well, OK, the oligarchs made a big service by creating identifiable property rights, but it is hard not to see that at least for a while society had to pay a heavy price for it - lost half of its GDP (and million, probably as many as 3 million in Russia alone -as Lawrence King and coauthors ague - lost their life years before they were due to appear before their Creator).

Nothing can be further from me than to moralize about this and blame the oligarchs. Most of them are shrewd, young and smart entrepreneurs who used the opportunities which were inevitably created in a system which intended to turn within 500 days an economy wholly publicly owned into individual private ownership. And this all was managed under the gaze of the benevolent patrimonial ruler who was looking for the ablest young people (almost exclusively men) who will manage now the newly acquired property efficiently to serve the leadership of the ruler. If they ever lost sight of it they were severely punished (I already mentioned Berezovsky and Khodorkovsky). But at least for the early years the relationship of the new barons and their subjects was also patrimonial. The oligarchs were rich out of the grace of the ruler so the new barons also "took care" of their subjects. Workers may not have been paid, but they were less likely to be laid off than their comrades under a neo-liberal regime. Instead of receiving a wage they might have gotten a plot on which they could grow their food, the firm which employed them bartered food for them for the industrial products they produced; if they worked in agribusiness they received bartered clothing instead of a wage.

This was workable but of course unsustainable. By the second decade of the transition the capital accumulated from speculation is turned into drilling oil, mining copper etc. and the relationship between the political bosses and the new grand bourgeoisie, the employers and employees had to be renegotiated.

The second decade as we will see is a productive one, but it is more authoritarian rather than patrimonial.

But let me comment first on the cross-national differences among the FUS-5 countries. 


\begin{tabular}{|c|c|c|c|c|c|c|c|c|c|}
\hline \multicolumn{10}{|c|}{ BELARUS $^{1}$} \\
\hline 1989 & 1990 & 1991 & 1992 & 1993 & 1994 & 1995 & 1996 & 1997 & 1998 \\
\hline \multicolumn{10}{|c|}{ GDP annual growth } \\
\hline 8 & -3 & -1 & -10 & -8 & -12 & -10 & 3 & 11 & 8 \\
\hline \multicolumn{10}{|c|}{ Unemployment rate } \\
\hline $\mathrm{Na}$ & 2 & 10 & 15 & 16 & 19 & 14 & 13 & 15 & 16 \\
\hline \multicolumn{10}{|c|}{ Labor force participation rate ${ }^{2}$} \\
\hline na & 67 & 66 & 65 & 64 & 63 & 62 & 62 & 61 & 60 \\
\hline \multicolumn{10}{|c|}{ Public debt (\% of GDP) } \\
\hline $\mathrm{Na}$ & $\mathrm{Na}$ & $\mathrm{Na}$ & $\mathrm{Ma}$ & $\mathrm{Na}$ & $\mathrm{Na}$ & 18 & 10 & 12 & 11 \\
\hline \multicolumn{10}{|c|}{$\mathrm{GINI}^{3}$} \\
\hline $22.8^{4}$ & $\mathrm{Na}$ & $\mathrm{Na}$ & $\mathrm{Na}$ & 21.6 & $\mathrm{Na}$ & 28.8 & $\mathrm{Na}$ & $\mathrm{Na}$ & 30.3 \\
\hline \multicolumn{10}{|c|}{ Life expectancy at birth ${ }^{5}$} \\
\hline 71.6 & 70.8 & 70.4 & 70.0 & 69.0 & 68.8 & 68.5 & 68.6 & 68.5 & 68.4 \\
\hline
\end{tabular}

\begin{tabular}{|c|c|c|c|c|c|c|c|c|c|}
\hline \multicolumn{10}{|c|}{ KAZAKHSTAN $^{6}$} \\
\hline 1989 & 1990 & 1991 & 1992 & 1993 & 1994 & 1995 & 1996 & 1997 & 1998 \\
\hline \multicolumn{10}{|c|}{ GDP annual growth ${ }^{7}$} \\
\hline $\mathrm{Na}$ & $\mathrm{Na}$ & -11.0 & -5.3 & -9.2 & -12.6 & -8.2 & .5 & 1.7 & -1.9 \\
\hline \multicolumn{10}{|c|}{${\text { Unemployment } \text { rate }^{8}}$} \\
\hline $\mathrm{Na}$ & $\mathrm{Na}$ & $\mathrm{Na}$ & $\mathrm{Na}$ & $\mathrm{Na}$ & 7.5 & 11.0 & 13.0 & 13.0 & 13.1 \\
\hline \multicolumn{10}{|c|}{ Labor force participation rate ${ }^{9}$} \\
\hline na & 70 & 70 & 70 & 70 & 70 & 70 & 70 & 70 & 70 \\
\hline \multicolumn{10}{|c|}{ Public debt (\% of GDP) } \\
\hline & & & & & & & & & \\
\hline \multicolumn{10}{|c|}{$\mathrm{GINI}^{10}$} \\
\hline $25.7^{11}$ & $\mathrm{Na}$ & $\mathrm{Na}$ & $\mathrm{Na}$ & 32.7 & $\mathrm{Na}$ & $\mathrm{Na}$ & 35.3 & $\mathrm{Na}$ & $\mathrm{Na}$ \\
\hline \multicolumn{10}{|c|}{ Life expectancy at birth ${ }^{12}$} \\
\hline $68.9^{13}$ & 68.3 & 68.0 & 67.7 & 66.3 & 65.7 & 64.9 & 64.1 & 64.5 & 64.6 \\
\hline \multicolumn{10}{|c|}{ RUSSIA $^{14}$} \\
\hline 1989 & 1990 & 1991 & 1992 & 1993 & 1994 & 1995 & 1996 & 1997 & 1998 \\
\hline
\end{tabular}

1 Data from www.ebrd/economicsstatistics

$2 \%$ of total population ages 15+, see www.worldbank.org/indicator/SL.TFL.CACT.ZS

3 Data from www.google.com/publicdata (from World Bank)

$4 \quad 1988$

5 Data from www.google.com/publicdata (from World Bank)

6 Data from www.ebrd/economicsstatistics

7 Data from www.google.com/publicdata (from World Bank)

8 Data from www.google.com/publicdata (from World Bank)

$9 \%$ of total population ages $15+$, see www.worldbank.org/indicator/SL.TFL.CACT.ZS

10 Data from www.google.com/publicdata (from World Bank)

$11 \quad 1988$

12 Data from www.goofle.com/publicdata (from World Bank)

131988

14 Data from www.ebrd/economicsstatistics 


\begin{tabular}{|c|c|c|c|c|c|c|c|c|c|}
\hline \multicolumn{10}{|c|}{ GDP annual growth } \\
\hline 2 & -3 & -5 & -15 & -9 & -13 & -4 & -4 & 1 & -5 \\
\hline \multicolumn{10}{|c|}{ Unemployment rate } \\
\hline $\mathrm{Na}$ & $\mathrm{Na}$ & $\mathrm{Na}$ & 5 & 6 & 8 & 9 & 9 & 11 & 12 \\
\hline \multicolumn{10}{|c|}{ Labor force participation rate ${ }^{15}$} \\
\hline na & 68 & 67 & 66 & 63 & 61 & 61 & 60 & 58 & 57 \\
\hline \multicolumn{10}{|c|}{ Public debt (\% of GDP) } \\
\hline $\mathrm{Na}$ & $\mathrm{Na}$ & $\mathrm{Na}$ & $\mathrm{Na}$ & $\mathrm{Na}$ & 48 & 46 & 49 & 57 & 82 \\
\hline \multicolumn{10}{|c|}{$\mathrm{GINI}^{16}$} \\
\hline $23.8^{17}$ & $\mathrm{Na}$ & $\mathrm{Na}$ & $\mathrm{Na}$ & 48.4 & $\mathrm{Na}$ & $\mathrm{Na}$ & 46.1 & $\mathrm{Na}$ & $\mathrm{Na}$ \\
\hline \multicolumn{10}{|c|}{ Life expectancy at birth ${ }^{18}$} \\
\hline 69.2 & 68.9 & 68.5 & 66.9 & 64.9 & 64.5 & 65.2 & 66.2 & 67.0 & 66.8 \\
\hline
\end{tabular}

\begin{tabular}{|c|c|c|c|c|c|c|c|c|c|}
\hline \multicolumn{10}{|c|}{ UKRAINE $^{19}$} \\
\hline 1989 & 1990 & 1991 & 1992 & 1993 & 1994 & 1995 & 1996 & 1997 & 1998 \\
\hline \multicolumn{10}{|c|}{ GDP annual growth ${ }^{20}$} \\
\hline 3.9 & -6.4 & -8.4 & -9.7 & -14.2 & -22.9 & -12.2 & -10.0 & -3.0 & -1.9 \\
\hline \multicolumn{10}{|c|}{ Unemployment rate ${ }^{21}$} \\
\hline $\mathrm{Na}$ & $\mathrm{Na}$ & $\mathrm{Na}$ & $\mathrm{Na}$ & $\mathrm{Na}$ & $\mathrm{Na}$ & 5.6 & 7.6 & 8.9 & 11.3 \\
\hline \multicolumn{10}{|c|}{ Labor force participation rate ${ }^{22}$} \\
\hline na & 63 & 62 & 62 & 61 & 61 & 60 & 60 & 59 & 59 \\
\hline \multicolumn{10}{|c|}{ Public debt (\% of GDP) } \\
\hline $\mathrm{Na}$ & $\mathrm{Na}$ & $\mathrm{Na}$ & $\mathrm{Na}$ & $\mathrm{Na}$ & $\mathrm{Na}$ & 22 & 24 & 30 & 38 \\
\hline \multicolumn{10}{|c|}{$\mathrm{GINI}^{23}$} \\
\hline $23.3^{24}$ & $\mathrm{Na}$ & $\mathrm{Na}$ & 25.7 & $\mathrm{Na}$ & $\mathrm{Na}$ & 39.3 & $\mathrm{Na}$ & $\mathrm{Na}$ & $\mathrm{Na}$ \\
\hline \multicolumn{10}{|c|}{ Life expectancy at birth ${ }^{25}$} \\
\hline 70.5 & 70.1 & 68.9 & 68.9 & 67.9 & 67.9 & 67.1 & 67.3 & 67.3 & 68.0 \\
\hline \multicolumn{10}{|c|}{ TURKMENISTAN ${ }^{26}$} \\
\hline 1989 & 1990 & 1991 & 1992 & 1993 & 1994 & 1995 & 1996 & 1997 & 1998 \\
\hline \multicolumn{10}{|c|}{ GDP annual growth ${ }^{27}$} \\
\hline-4.9 & .7 & -4.7 & -5.3 & -10.0 & -17.3 & -7.2 & -6.7 & $-11,3$ & 6.7 \\
\hline \multicolumn{10}{|c|}{ Unemployment rate ${ }^{28}$} \\
\hline na & $\mathrm{Na}$ & $\mathrm{Na}$ & $\mathrm{Na}$ & na & $\mathrm{Na}$ & na & na & na & $\mathrm{Na}$ \\
\hline \multicolumn{10}{|c|}{ Labor force participation rate ${ }^{29}$} \\
\hline na & 60 & 60 & 60 & 60 & 60 & 60 & 60 & 60 & 60 \\
\hline \multicolumn{10}{|c|}{ Public debt (\% of GDP) } \\
\hline na & $\mathrm{Na}$ & $\mathrm{Na}$ & $\mathrm{Na}$ & na & $\mathrm{Na}$ & na & na & na & $\mathrm{Na}$ \\
\hline \multicolumn{10}{|c|}{$\mathrm{GINI}^{31}$} \\
\hline $26.4^{32}$ & $\mathrm{Na}$ & $\mathrm{Na}$ & $\mathrm{Na}$ & 35,4 & $\mathrm{Na}$ & $\mathrm{Na}$ & na & $\mathrm{Na}$ & 40.8 \\
\hline \multicolumn{10}{|c|}{ Life expectancy at birth ${ }^{33}$} \\
\hline 62.6 & 62.7 & 62.7 & 62.7 & 62.7 & 62.9 & 63.0 & 65.2 & 63.4 & 63.6 \\
\hline $\begin{array}{ll}15 & \% \\
16 & D\end{array}$ & 1 pop & n age & years & see ww & orldbar & g/indi & /SL.TF & CT.ZS & \\
\hline
\end{tabular}


The description of neo-patrimonial order offered before fits reasonable well Russia and the Ukraine, but it is at best a rough estimation of the actual socio-economic processes and structures in Belarus, Kazakhstan and Turkmenistan.

The Belarus comes close to something one could call a neo-Stalinist state. Belarus carried out some privatization, but the public sector is still the dominant one. Its post-Soviet recession (hard to call it transformational recession, since Belarus did not experience as of yet much of a transformation) was somewhat milder than in Russia or the Ukraine, though the unemployment rate in Belarus was substantially higher and the decline in life expectancy almost as bad as in Russia. Slow or little reform did not protect Belarus from the crisis, though its economic performance after 1997 was respectable. Its economy bottomed earlier (1996) while the other countries - each one of them, especially Russia, Kazakhstan and Turkmenistan better endowed in natural resources - were still in free fall. While Belarus followed a different trajectory in terms of privatization than Russia it has a similar socio-political system as the other neo-patrimonial countries (and it has very close economic and political ties with Russia). Each of the neo-patrimonial regimes were (and still are) ruled by older men who were high or at least middle ranking officials in the Soviet political, economic or military/intelligence establishment. Kazakhstan's Nazerbayev was already the chairman of the council of ministers during soviet times; Belarus's Lukashenko was an officer of the Soviet Army and a mid-level manager during the 1980s; Turkmenistan's eccentric first post-Soviet president ("president for life") Niyazov was the first secretary of the Communist Party of Turkmenistan; Ukraine's Yanukovich was promoted to managerial positions during the 1980s despite his earlier criminal (NOT political, criminal-criminal) convictions and of course Russia's Putin was an officer of KGB. The rulers operate with a sophisticated network of clients and while in Russia and the Ukraine there is a somewhat competitive multi-party system, their democracy is highly "managed", in Belarus and Kazakhstan and especially in Turkmenistan there is little semblance of any democracy. All five countries are "presidential republics" with a strong institution of presidents who are not tested in particularly competitive elections (some of the elections - especially in Kazakhstan and Turkmenistan - are not competitive at all - giving $80-95 \%$ of the votes to the "candidates" - resembling elections in Soviet times).

$17 \quad 1988$

18 Data from www.google.com/publicdata (from World Bank)

19 Data from www.ebrd/economicsstatistics

20 Data from www.google.com/publicdata (from World Bank)

1 Data from www.google.com/publicdata (from World Bank)

$2 \%$ of total population ages $15+$, see www.worldbank.org/indicator/SL.TFL.CACT.ZS

3 Data from www.google.com/publicdata (from World Bank)

1988

5 Data from www.google.com/publicdata (from World Bank)

Data from www.ebrd/economicsstatistics

Data from www.google.com/publicdata (from World Bank)

28 Statistical data are state secret in Turkmenistan. Official statistics report $0 \%$ unemployment, but it is believed to be $60 \%$. That casts doubt on the labor force participation statistics as well. See CIA World Factbook, www. cia.gov

$29 \%$ of total population ages $15+$, see www.worldbank.org/indicator/SL.TFL.CACT.ZS

30 Data from www.google.com/publicdata (from World Bank)

$31 \quad 1988$

32 Data from www.google.com/publicdata (from World Bank)

33 Data from Index Mundi, CIA World Fact-book 
Kazakhstan and Turkmenistan are Turkic states - used to be rather nomadic nations before incorporated into the USSR - with the majority of their population is Muslim and both regimes increasingly - though still cautiously play the Islamic card.

Despite these differences in economic policies and historical-cultural background, the collapse of the Soviet Union impacted the countries in similar ways to a similar extent, hence defining them as travelling on a similar trajectory, distinctly different from Central European neo-liberalism and East Asian "capitalism from below" seems to be justified.

\section{The second phase of neo-patrimonial transition (1999-2010): economic explosion and fast recovery from the Global Financial Crisis}

The great surprise of the post-communist transformation is the aggressive recovery of neopatrimonial regimes. Social theory would predict that neo-patrimonial regime and economic modernizations are inconsistent hence the collapse of the 1990s impressed many of us as something anticipated. But starting the 1999 for ten uninterrupted years all countries I identified as neo-patrimonial were on a growth trajectory, some achieved double digit GDP growth and they outperformed the neo-liberal regimes and produced growth rates comparable to China.

The BIG puzzle of course is: are these countries so successful, because they are neo-patrimonial or to the contrary they are successful, because they are resource rich? Hard to tell, since both the crisis of the 1990 s and the explosion of the first decade of the $21^{\text {st }}$ century probably has as much to do with resource richness/dependency and the strategy of transition or the nature of the social-political regime.

There are really two schools of thought to explain the different dynamics of the 1990s and early $2000^{\text {th }}$. Among other commentators AsLund (2010) and Treisman (2010) claim that the collapse of the 1990s is overestimated and the resource curse is way exaggerated (Ruthland and others tend to agree). Russia (and arguably the region) is on the right track, neo-patrimonial or authoritarian order is transitory and eventually with economic growth and modernization Russia will also enter the democratic development (this is also consistent with Jeffrey Sachs, 2005).

Others attribute both the collapse and the recovery/and new downturn in the Russian economy to resource dependence. Russia fell so deeply in the 1990s, since oil prices plummeted - it recovered, since energy and mineral prices skyrocketed during the early years of the $21^{\text {st }}$ century and it fell sharply in 2008 again because the shrinking demand for raw materials and oil/gas. Sidosenko (2011) claims than even in 2010, 98 \% of Russia's export cane from natural resources and primary derivatives.

So was the impressive recovery simply the result of the increase of raw material and oil/gas prices or was there something else beyond it? Some argue after the 1998 financial crisis Russia (at least partially) re-industrialized. Given the collapse of the ruble import product became far too expensive hence a policy of import substitution led to some degree of re-industrialization. (KAdoChNikov 2006.) A complementary explanation is a rebuilding of state capacities under President Putin, as Peter Rutland put it a transition from Yeltsin's Oligarchic capitalism to "state guided capitalism" (for this distinction see also BAUMOL-LiTAN-SCHRA 2007.), what some may attribute to Putin. It is hard to tell how much of the success of the first two presidencies of Putin have to do with the "state guided" capitalist development (which in the spirit, if not in the words of Baumol and his co-authors may not be the best, but it is certainly not the worst either). An 
alternative explanation is that it is not so much the reasonable or even smart industrial policies of the Russian state, which leads to the expansion of the early years of the $21^{\text {st }}$ century, but the growth of oil, gas and mineral resource prices. The big question what only further careful research can answer: was Russia turning away from oligarchic capitalism to state led capitalism but - as Peter Rutland suggests - was it merely cash in the revenues of a rentier state.

The social science literature has begun to use the idea of rentier state (following to footsteps of Karl Marx idea of "rentier capitalism") since the 1970s (the first usage of the term is attributed to Hussein Mahdavy, 1970) to describe those economies, which generate especially high revenues from exports of mineral resources, especially petroleum may suffer from the so called resource curse. The high revenues from natural resource creates disincentives to develop other branches of the domestic economy (if natural resources are discovered in already developed countries that can cause the so called Dutch Disease, the new resource may draw capital and labor from already developed sectors, increases their expenses, a decrease their competitiveness). Hazem Behlam and Giacomo Luciani (1987) applied it to the Gulf Countries and in general Arab states, Douglas Yates (1996) applied it to Africa (Gabon, but others used it for Nigeria as well). Ahmet KuRU identified Turkmenistan as a rentier state (2002) to the best of my knowledge the first attempt to conceptualize neo-patrimonial post-communist regimes as "rentier" state. Turkmenistan with an estimated $40-60 \%$ unemployment rate, with then fourth largest oil and gas deposits in the world and with the highly authoritarian state qualifies perfectly for the label. Arguably Russia and Kazakhstan in the first decade of the $21^{\text {st }}$ century demonstrated rentier state characteristics. Both of these states have large mineral and oil resources and they dramatic growth fluctuated in strong correlation with the oil prices. Being a resource rich rentier state tends to be a mixed blessing or indeed can straight be a curse. Economists usually emphasize the long term negative impact on economic development, but resource wealth and the rentier character of the state can be a barrier to democratization as well (Ross 1999. 312.), rentier states can buy peace and diffuse political mobilization by generous welfare payments and let us add by maintaining strong oppressive apparatuses to keep those inline who does not benefit from those welfare provisions (like the guest workers in the Gulf States).

It is difficult if not impossible to make a clear distinction between patrimonial regimes and the authoritarian/rentier state. I call regimes patrimonial, if there is a patron-client relationship. So the early post-Soviet Russian state was patrimonial, since the new rich received its wealth as "patrimony" from the good-will of the ruler and employers were also expected to take care of their employees rather than laying them of and leaving them at the mercy of the welfare state. Hence GDP fell, but unemployment remained low. The relationship between the ruled and ruler was one of loyalty and mutual obligations. The oligarchic stage of Russian development (from mid 1990s until the end of Yeltsin's rule) was rather different, the oligarchs threatened the power of the rulers and they tended to act in a rather despotic manner towards their subordinates. The purest type of neo-patrimonial order were the early days of Yeltsin and especially the first years of Putin with his rather successful attempt to establish himself as the "good czar", poverty was reduced, GINI was declining and the regime - far from democratic - had substantial popular support. But the "good old days" are clearly gone; Russia is more and more obviously an authoritarian system. Some of the rentier states treat at least some of their subjects well and combine strict authoritarian rule for the majority with generous provisions from rents to a privileged 
minority. The clearest examples are the Gulf Monarchies, in particular Qatar and the United Arab Emirates where excessive exploitation of the "guest worker" majority (some 95 percent of the labor force in these countries are "guest workers", who work there on three year renewable visa) with Scandinavian style welfare provisions for the 10 percent "natives" (Christopher Davidson, the best scholar of UAE hesitates to call it "tribal capitalism" ( DAVIDSON 2009.) or "retier state" (DAVIDSON 2005. 298.). Undoubtedly, tribal capitalism, or neo-patrimonial regime implies more the notions of loyalty, obedience, mutual obligations, while rentier state refers to oppressive and exploitative practices. The shift from neo-patrimonial to authoritarian/rentier state is discernible in the successor countries of the former USSR, Belarus being on one end of the scale Turkmenistan on the other end of the spectrum.

\begin{tabular}{|c|c|c|c|c|c|c|c|c|c|c|c|}
\hline \multicolumn{12}{|c|}{ BELARUS $^{34}$} \\
\hline 1999 & 2000 & 2001 & 2002 & 2003 & 2004 & 2005 & 2006 & 2007 & 2008 & 2009 & 2010 \\
\hline \multicolumn{12}{|c|}{ GDP annual growth } \\
\hline 1.5 & 4 & 4.1 & 4.2 & 6.8 & 6.4 & 9.2 & 9.9 & 8.2 & 10 & .2 & 7.6 \\
\hline \multicolumn{12}{|c|}{ Unemployment rate } \\
\hline $\mathrm{Na}$ & 2.3 & 2.1 & 2.1 & 2.1 & 2.1 & 1.6 & 1.6 & 1.6 & 1.6 & 1.0 & $\mathrm{Na}$ \\
\hline \multicolumn{12}{|c|}{ Labor force participation rate ${ }^{35}$} \\
\hline 59 & 58 & 58 & 58 & 57 & 57 & 56 & 56 & 56 & 55 & 55 & 56 \\
\hline \multicolumn{12}{|c|}{ Public debt $(\% \text { of GDP })^{36}$} \\
\hline 13 & 17 & 13 & 11 & 10 & 10 & 9 & 8 & 9 & $\mathrm{Na}$ & $\mathrm{Na}$ & $\mathrm{Na}$ \\
\hline \multicolumn{12}{|c|}{ Population below poverty line } \\
\hline $\mathrm{Na}$ & $\mathrm{Na}$ & $\mathrm{Na}$ & $\mathrm{Na}$ & 27.1 & $\mathrm{Na}$ & $\mathrm{Na}$ & $\mathrm{Na}$ & $\mathrm{Na}$ & $\mathrm{Na}$ & $\mathrm{Na}$ & $\mathrm{Na}$ \\
\hline \multicolumn{12}{|c|}{ GINI } \\
\hline $\mathrm{Na}$ & $\mathrm{Na}$ & $\mathrm{Na}$ & $\mathrm{Na}$ & $\mathrm{Na}$ & $\mathrm{Na}$ & $\mathrm{Na}$ & $\mathrm{Na}$ & $\mathrm{Na}$ & 27.2 & $\mathrm{Na}$ & $\mathrm{Na}$ \\
\hline \multicolumn{12}{|c|}{ Life expectancy at birth } \\
\hline $\mathrm{Na}$ & 68.0 & 68.1 & 68.3 & 68.4 & 68.6 & 68.7 & 69.1 & 70.1 & 70.3 & 70.6 & 70.9 \\
\hline \multicolumn{12}{|c|}{ KAZAKHSTAN $^{37}$} \\
\hline 1999 & 2000 & 2001 & 2002 & 2003 & 2004 & 2005 & 2006 & 2007 & 2008 & 2009 & 2010 \\
\hline \multicolumn{12}{|c|}{ GDP annual growth } \\
\hline 1.7 & 10.5 & 12.2 & 9.5 & 9.2 & 9.1 & 9.5 & 10.6 & 8.5 & 2.4 & 1.2 & 7.0 \\
\hline \multicolumn{12}{|c|}{ Unemployment rate } \\
\hline $\mathrm{Na}$ & $\mathrm{Na}$ & 10.0 & 8.8 & 8.8 & 8.0 & 8.1 & 7.4 & 7.3 & 6.6 & 6.3 & 5.5 \\
\hline \multicolumn{12}{|c|}{ Public debt (\% of GDP) } \\
\hline $\mathrm{Na}$ & na & $\mathrm{Na}$ & $\mathrm{Na}$ & $\mathrm{Na}$ & 13.7 & 10.5 & 11.0 & 7.7 & 8.9 & 14.2 & 16.2 \\
\hline \multicolumn{12}{|c|}{ Labor force participation rate ${ }^{38}$} \\
\hline 70 & 70 & 70 & 70 & 70 & 69 & 69 & 70 & 71 & 71 & 71 & 71 \\
\hline \multicolumn{12}{|c|}{ Population below poverty line } \\
\hline 35.0 & $\mathrm{Na}$ & 26.0 & $\mathrm{Na}$ & $\mathrm{Na}$ & 19.0 & $\mathrm{Na}$ & $\mathrm{Na}$ & 13.8 & 12.1 & 8.2 & $\mathrm{Na}$ \\
\hline
\end{tabular}

$34 \%$ of total population ages $15+$, see www.worldbank.org/indicator/SL.TFL.CACT.ZS

35 Data 1999-2007 are from www.ebrd/economicsstatistics

36 Data from Index Mundi, CIA World Fact-book

$37 \%$ of total population ages $15+$, see www.worldbank.org/indictor/.SL.TFL.CACT.ZS

38 Data from www.google.com/publicdata 


\begin{tabular}{|l|c|c|c|c|c|c|c|c|c|c|c|}
\hline \multicolumn{1}{|c|}{ GINI } \\
\hline $\mathrm{Na}$ & $\mathrm{Na}$ & $\mathrm{Na}$ & $\mathrm{Na}$ & 31.5 & $\mathrm{Na}$ & $\mathrm{Na}$ & $\mathrm{Na}$ & $\mathrm{Na}$ & $\mathrm{Na}$ & 26.7 & $\mathrm{Ma}$ \\
\hline \multicolumn{10}{|c|}{ Life expectancy at birth } \\
\hline $65.5^{39}$ & 63.2 & 63.3 & 63.4 & 63.5 & 66.1 & 66.6 & 66.9 & 67.2 & 67.6 & 67.9 & 68.2 \\
\hline
\end{tabular}

\begin{tabular}{|c|c|c|c|c|c|c|c|c|c|c|c|}
\hline \multicolumn{12}{|c|}{ RUSSIA $^{40}$} \\
\hline 1999 & 2000 & 2001 & 2002 & 2003 & 2004 & 2005 & 2006 & 2007 & 2008 & 2009 & 2010 \\
\hline \multicolumn{12}{|c|}{ GDP annual growth } \\
\hline 3.2 & 6.3 & $\mathrm{Na}$ & 4.2 & 7.3 & 6.7 & 6.4 & 6.7 & 8.1 & 5.6 & -7.9 & 4.0 \\
\hline \multicolumn{12}{|c|}{ Unemployment rate } \\
\hline 12.4 & 10.5 & 8.0 & $\mathrm{Na}$ & 7.9 & 8.5 & 8.3 & 7.6 & 6.2 & 6.4 & 8.4 & 7.6 \\
\hline \multicolumn{12}{|c|}{ Labor force participation rate ${ }^{41}$} \\
\hline 61 & 61 & 60 & 60 & 60 & 60 & 60 & 61 & 62 & 63 & 63 & 63 \\
\hline \multicolumn{12}{|c|}{ Public debt (\% of GDP $)^{42}$} \\
\hline 90 & 63 & 48 & 41 & 32 & 28.2 & 12.9 & 8.0 & 5.9 & 6.7 & 8.3 & 9.5 \\
\hline \multicolumn{12}{|c|}{ Population below poverty line } \\
\hline 40.0 & $\mathrm{Na}$ & $\mathrm{Na}$ & 25.0 & 25.0 & 17.8 & $\mathrm{Na}$ & $\mathrm{Na}$ & 15.8 & $\mathrm{Na}$ & 13.1 & $\mathrm{Na}$ \\
\hline \multicolumn{12}{|c|}{ GINI } \\
\hline $\mathrm{Na}$ & $\mathrm{Na}$ & 39.9 & $\mathrm{Na}$ & $\mathrm{Na}$ & $\mathrm{Na}$ & $\mathrm{Na}$ & $\mathrm{Na}$ & $\mathrm{Na}$ & $\mathrm{Na}$ & 42.2 & $\mathrm{Na}$ \\
\hline \multicolumn{12}{|c|}{ Life expectancy at birth } \\
\hline $\mathrm{Na}$ & 67.2 & 67.3 & 67.5 & 67.7 & 66.4 & 67.1 & 67.1 & 65.9 & 66.0 & 66.0 & 66.2 \\
\hline \multicolumn{12}{|c|}{ UKRAINE $^{43}$} \\
\hline 1999 & 2000 & 2001 & 2002 & 2003 & 2004 & 2005 & 2006 & 2007 & 2008 & 2009 & 2010 \\
\hline \multicolumn{12}{|c|}{ GDP annual growth } \\
\hline-.4 & 6.0 & 9.0 & 4.1 & 9.4 & 12.0 & 2.6 & 7.1 & 7.7 & 2.7 & -15.1 & 4.2 \\
\hline \multicolumn{12}{|c|}{ Unemployment rate } \\
\hline $\mathrm{Na}$ & 4.3 & 4.3 & 3.6 & 3.8 & 3.7 & 3.5 & 3.1 & 2.7 & 3.0 & 8.8 & 8.4 \\
\hline \multicolumn{12}{|c|}{ Labor force participation rate ${ }^{44}$} \\
\hline 58 & 58 & 57 & 57 & 57 & 57 & 58 & 58 & 58 & 59 & 59 & 59 \\
\hline \multicolumn{12}{|c|}{ Public debt (\% of GDP) ${ }^{45}$} \\
\hline 51 & 46 & 37 & 34 & 29 & 24.7 & 17.0 & 12.7 & 11.7 & 10.3 & 30.0 & 38.4 \\
\hline \multicolumn{12}{|c|}{ Population below poverty line } \\
\hline 50.0 & $\mathrm{Na}$ & 29.0 & $\mathrm{Na}$ & 37.7 & $\mathrm{Na}$ & $\mathrm{Na}$ & $\mathrm{Na}$ & $\mathrm{Na}$ & $\mathrm{Na}$ & 35.0 & $\mathrm{Na}$ \\
\hline \multicolumn{12}{|c|}{ GINI } \\
\hline 29.0 & $\mathrm{Na}$ & $\mathrm{Na}$ & $\mathrm{Na}$ & $\mathrm{Na}$ & $\mathrm{Na}$ & $\mathrm{Na}$ & $\mathrm{Na}$ & $\mathrm{Na}$ & 27.5 & $\mathrm{Na}$ & $\mathrm{Na}$ \\
\hline
\end{tabular}

39 Data from Index Mundi, CIA World Fact-book

$40 \%$ of total population ages $15+$, see www.worldbank.org/indictor/.SL.TFL.CACT.ZS

41 Data 1999-2003 are from www.ebrd/economicsstatistics

42 Data from Index Mundi, CIA World Fact-book

$43 \%$ of total population ages $15+$, see www.worldbank.org/indicator/SL.TFL.CACT.ZS

44 Data 1999-2003 are from www.ebrd/economicsstatistics

45 Data from Index Mundi, CIA World Fact-book 


\begin{tabular}{|c|c|c|c|c|c|c|c|c|c|c|c|}
\hline \multicolumn{12}{|c|}{ Life expectancy at birth } \\
\hline $\mathrm{Na}$ & 66.0 & 66.2 & 66.3 & 66.5 & 66.7 & 69.7 & 70.0 & 67.9 & 68.1 & 68.2 & 68.5 \\
\hline \multicolumn{12}{|c|}{ TURKMENISTAN ${ }^{46}$} \\
\hline 1999 & 2000 & 2001 & 2002 & 2003 & 2004 & 2005 & 2006 & 2007 & 2008 & 2009 & 2010 \\
\hline \multicolumn{12}{|c|}{ GDP annual growth } \\
\hline 16.5 & 18.6 & 20.4 & 15.8 & 17.' & 17.2 & 13.0 & 11.4 & 11.8 & 14.7 & 6.1 & 9.2 \\
\hline \multicolumn{12}{|c|}{ Unemployment rate } \\
\hline $\mathrm{Na}$ & na & na & $\mathrm{Na}$ & na & na & $\mathrm{Na}$ & $\mathrm{Na}$ & na & $\mathrm{Na}$ & na & na \\
\hline \multicolumn{12}{|c|}{ Labor force participation rate ${ }^{47}$} \\
\hline 60 & 61 & 61 & 61 & 61 & 61 & 61 & 61 & 61 & 61 & 61 & 61 \\
\hline \multicolumn{12}{|c|}{ Population below poverty line } \\
\hline $\mathrm{Na}$ & na & $\mathrm{Na}$ & na & $\mathrm{Na}$ & $\mathrm{Na}$ & $\mathrm{Na}$ & $\mathrm{Na}$ & $\mathrm{Na}$ & $\mathrm{Na}$ & $\mathrm{Na}$ & $\mathrm{Na}$ \\
\hline \multicolumn{12}{|c|}{ GINI } \\
\hline $\mathrm{Na}$ & na & $\mathrm{Na}$ & na & $\mathrm{Na}$ & $\mathrm{Na}$ & $\mathrm{Na}$ & $\mathrm{Na}$ & $\mathrm{Na}$ & $\mathrm{Na}$ & $\mathrm{Na}$ & $\mathrm{Na}$ \\
\hline \multicolumn{12}{|c|}{ Life expectancy at birth } \\
\hline 63.8 & 63.9 & 64.0 & 64.1 & 64.3 & 64.4 & 64.4 & 64.5 & 64.6 & 64.7 & 64.8 & 64.9 \\
\hline
\end{tabular}

Belarus and the Ukraine are outliers. Belarus is poor in mineral resources and the Ukraine is also rather poor. It is more the political system what binds these countries together than the political economy. While the sharp drop of GDP during the first decade in Russia, Kazakhstan and Turkmenistan clearly is related to the moderation of oil prices and their explosive growth for the most part in the first decade of the $21^{\text {st }}$ century was caused by the new oil boom, Belarus and Ukraine's economy cycle has more to do with their dependence on the Russian economy (and during the Global Financial Crisis the collapse of the Ukrainian economy also on its increasing dependence on the world markets and EU).

Despite the spectacular growth of neo-patrimonial regimes during the second decade of the transition, it is unlikely the success can be attributed to neo-patrimonial nature of the regime. These regimes were turning rentier states with highly and probably increasingly authoritarian systems. On balance neo-liberalism performed slightly better, but the only unqualified success story is Poland and it is hard to tell whether Poland was so successful, since it was pursuing the neo-liberal prescription more closely, or to the contrary, because it was somewhat less dependent of international capital. There is little doubt that both neo-liberal and neo-patrimonial regimes did better than they would have done would have stayed on the state socialist trajectory, but the road from socialism was and remained rocky. The nostalgia for the communist past which is still haunting the region is on the whole silly - people are freer and most of them live better than they or their parents used to live twenty years ago, so the nostalgia is either romanticizing the past when people were younger or a reasonable expression of anxiety in a new world where there is less security and more risk taking - nevertheless, the hopes of the late 80 s or early $90 \mathrm{~s}$ were hardly met and disappointment is widespread - often expressed by shift to the far right - is a major fact of post-communist social life in the former communist countries of Europe. Ivan T.

\footnotetext{
$46 \%$ of total population ages $15+$, see www.worldbank.org/indicator/SL.TFL.CACT.ZS

47 Wor4ld Bank estimate, using \$1.08 per day per capita consumption with 1993 PPP, see China from Poor Areas to Poor People. Report No. 37349-CN, March 2009, Washington DC.: The world Bank
} 
Berend formulated the problem even for the most successful neo-liberal trajectory so astutely: 1944-1993 was a "detour from the periphery to the periphery" (BEREND 1998).

During the early 1990s, I met David Stark several times at various conferences and he often recited an old Irish joke: two men meets somewhere in Ireland. The first one asks: "Which is the best road from here to Belfast?" The other responds: "Do not start it from here." Good joke, but overstates the importance of the initial conditions and understates the policy errors made in selecting the pathways.

This leads us to the last section of this paper: the special trajectory China followed. We are often warned (SACHS 2005.) to be very careful in comparing the Chinese transformation with the post-Soviet and post-socialist European transition. Ironically, the argument is just the opposite of the Irish joke. The Irish joke implies: the problem is with the initial condition, you would easily get to Belfast, if you started from a better position. Now the Chinese initial conditions without doubt were the worst. So if China - unlike the former USSR or its European satellites - is a success story, it should not be attributed to the worst initial condition, it can be the outcome of the "advantages" of backwardness (to invoke Gershenkron 1962.), so either the inverse of the Irish joke is correct, or the Irish joke is incorrect, what matters is not the initial condition, but the selection of appropriate policies.

I am sitting tightly on the fence when I have to evaluate what matters more: initial conditions or policy choices. Both matter. The Czechs may have made some policy errors they still of all right, since their point of departure was so much better; the Hungarian initial conditions were pretty good and they may do poorly by now since they made some policy errors, the Poles were not in great shape during the 1980s, now they do better, probably because they made some good policy choices.

So the big question for the last section: can one claim that the Chinese did something right or they simply do fine because, they started from the very bottom (the benefit from the advantages of backwardness)?

\section{“Capitalism from below"}

There is a third pathway from redistribution to markets which can be identified with East Asian socialism, China (and Vietnam). In contrast with the neo-liberal and neo-patrimonial trajectory which created capitalism by design, built the transition from above in East Asia, the drift from state socialist redistributive economy started from below. The nature of the Chinese formation and the driving forces behind its undisputable (though not necessarily sustainable) economic success is the subject of some controversy. According to the official ideology, China is "market socialism" (which is just a stage on the road to communism), while most Western commentators emphasize the capitalist features of China today. Some underline the "Chinese characteristics" (HuANG 2008.) of its capitalism, Victor Nee is his earlier work saw "hybrid" elements in the Chinese formation, but in his latest book, "Capitalism from Below" (NeE 2012.) he sees private entrepreneurship as force behind China's growth. Philip HUANG (2012) in contrast objects to the binary opposition between public and private, capitalism and socialism but he emphasizes the central role of local (and central) government and the public sector in fermenting social and economic development. He is inspired by the work of Jean Oi and her theory of 'local state corporatism' (OI 1992, 1999.) who emphasized that the success of rural China cannot be merely attributed to raise of the private sector; the local state manages to use revenues from 
Township and Village Enterprises (TVE's) to meet local social needs (fund education, healthcare etc.) when the central state cannot provide for such goals any longer. Is a "state centered" - change from above - (Oi) or "society centered" change from below - (Nee) centered explanation a better fit with the data?

Greatly influenced by Nee's early work (NeE 1989.), I introduced the idea of "capitalism from below" (Eyal and all, 1998. and KING - Szelenyi 2005.) to distinguish the Chinese way from the neo-liberal and neo-patrimonial trajectory away from socialism. My proposal was not quite as radical as Nee's new theory is, but I made the following assumptions:

Unlike the neo-liberal and neo-patrimonial shock therapeutic ways of making capitalism the drift away from redistribution to markets has been gradual in China (and after the mid 1980s in Vietnam). How gradual it was is disputed (Sachs for instance argues de-collectivization in China was sufficiently a 'shock', Sachs, 2005), but "transformation from below" never experienced fast mass privatization; deregulation of state control over the economy was spread over years or decades, while it (convertibility of currency, elimination of tariff barriers etc) occurred in neo-liberal and neo-patrimonial regimes almost over-night;

(ii) In China the transformation started in the agrarian sector by shifting first production and next marketing/distribution of products from the agricultural collectives to individual peasant households. Another engine of early economic take-off for reform China was the success of Township and Village Enterprises (TVEs). The property rights of TVEs during the 1980s were the subject of heated debates. TVEs officially were collectives and operated under local government control. Hence many commentators regarded the success of TVEs as proof of the central role collective (rather than private) firms (see HuANG 2012.; Or 1999 among others). Others (Yasheng Huang and others) claimed that the majority of TVEs were private businesses. According to Yasheng Huang, only 1.5 million out of the 12 million TVEs during the mid 1980s were publicly owned (HuANG 2008. 79.). Incidentally one unanticipated - by most Western observers on the political left and right - outcome of this "market transition" (Nee pointed this out in 1989) was the improvement in the living conditions of rural masses, the shrinking of inequality between rural and urban population, between cadres and the rest of the society, especially peasantry.

While I still believe this was a reasonably correct analysis of the Chinese reform of the 1980s, my earlier position needs to be reconsidered. During the 1990s and the first decade of the $21^{\text {st }}$ century there was some convergence with the neo-liberal/neo-patrimonial model. Yasheng Huang called this as the "great reversal" - the shift away from an entrepreneurial trajectory to a state directed one ((HuANG 2008. 109-174). Yasheng Huang is far from an advocate of socialism - to the contrary, he has been critical of the evolution in China during the 1990s since it drifted away from entrepreneurial capitalism a more statist mode (what Philip Huang - much more sympathetic to the causes of socialism - is inclined to call "state capitalism"). Nevertheless, it is hard to dispute that there was substantial re-centralization during the 1990s (the most important was arguably the change in the taxation system, Beijing regained a great deal of taxation authority and the balance of power shifted back from the province and localities which were quite well off during local state corporatism" the center, which suddenly was flooded with resources).

Let me illustrate this one anecdote. In 1995, I was in Beijing with my dear colleagues, Andrew Walder and Donald Treiman. One evening we were walking around - thirsty - in the Forbidden City. We saw light on in an ancient building and it turned out to be a "Bier Stube". So we had our Tsingtao Beer when it turned out Andy actually knew the manager who was making his tour 
around the guests. That person turned out to be an employee of the National Archives where Andy did a great deal of research. We eventually learned that the "Bier Stube" is a side-branch of the National Archives. The funding was so much cut for the archive that in order to survive, they had to start some business venture to supplement their resources. We gathered around that time even the central Chinese intelligence agency had to run a hotel in downtown Beijing not so much to have easier access for the surveillance of foreign guests, but because they needed the funds from the business. These were times of the poor central state (with reasonably well to do local states). When I was back in Beijing in 2010, all seem to have changed. Beijing was flooded with resources. The Sociology department at Tsinghua University had better resources than Yale and Beijing was flooded with money (I also recall the rather inadequate facilities of the People's University in Beijing during our visits during the early 1990s).

Well, one can object: but was it not 1997 that China started to privatize the corporate sector? Absolutely, but the question is: how did that "privatization" take place? But Yasheng Huang casts some doubts on the privatization of public sector. He suggests that IMF statistics which claims that only about $25 \%$ of the non-agrarian production comes from the public sector simply identifies "legal persons" when they are indicated as owners of a form as "private owners". According to Yasheng Huang, these "legal persons" often stand for public entities, for instance for government owned banks or firms largely owned by government banks (Op cit, 15-16). Hence Chinese privatization maybe quasi-privatization and the contribution of the public sector to the non-agrarian GDP may be somewhere $50-75 \%$ (these figure are similar to the data provided by Philip Huang, who is of rather different political persuasion).

While it can (and IS) be contested how large the private vs. the public sector is, whether the state or the private sector leads Chinese economic growth all sides tend to agree that during the 1990s social inequalities increased substantially in China. During 1978 and 1985 GINI was moderated (much to the surprise of Western left-wingers GINI was actually quite high at the end of the Mao area and during market reform it was moderated) but after 1985, and especially during the 1990s inequalities (and most disturbingly the urban-rural inequalities) skyrocketed. While GINI in China today is not all that different from the USA most commentators agree (and in this respect by Yasheng Huang and Philip Huang are on the same side) it is untenably high and unlike the first decade of the reform the second two decades had some serious negative social consequences, which eventually needs to be addressed.

According to Yasheng Huang, China during the second half of the first decade of the $21^{\text {st }}$ century, during the $\mathrm{Hu}$-Wen regime China began to address these issues, paying more attention to rural development and social inequality. The dominant ideology of the first decade of the $21^{\text {st }}$ century is "social harmony", an idea borrowed more from Confucianism rather than Marxism. While in Marxism-Maoism the emphasis is on equality the idea of social harmony can live with inequality as long as it accommodates the idea of harmony - some can be more privileged than others but they also need to have responsibility for those beneath them. It involves more the idea of solidarity and responsibility rather than equality.

Hence China's post reform (after 1978) development can be classified into three various stages, or epochs, "capitalism from below" (1978-1985 or possibly until the late 1980s, though following 1985 the Chinese leadership begins to respond to the dissatisfaction of the urban population to the "rural" bias of the early reform, but not sufficiently to prevent the 1989 revolutionary upheavals ); the "great reversal" (or the Chinese equivalent of capitalism from above, 1992-2002, the Jiang Zhu era, with 1989-1991 as a temporary reversal to pre-reform policies, 
with a strong pro-urban bias) and the post 2002 epoch (the Hu-Wen era) with an emphasis on "social harmony" and rural development.

What is constant in the Chinese case (and strikingly different from the former USSR and its European former satellites) is the fact that the CCP retained its power monopoly (though the ideology of Marxism-Leninism-Maoism is losing credibility and Confucianism is gaining ground) - it appears that it is still true in China by the second decade of the $21^{\text {st }}$ century that "politics is in command". In political terms China is still a "communist country".

The performance of Chinese way of drifting away from redistribution to market arguable had less social costs and more social and economic returns than the neo-liberal and neo-patrimonial trajectory. During the first three decades of its transformation, China produced double digit (or close to double digit) annual economic growth, and while inequality increased substantially after the first decade of the reform the number of Chinese below the poverty line was reduced by hundreds of millions. China also was almost unscratched by the global financial crisis. The Chinese entered the global fiscal crisis not only without sovereign debts, but with gigantic reserves and applied a massive doze of classical Keynesian stimulation package in a timely manner (Keith Bradsher, 2009). The way the \$US600 billion Chinese "stimulus package" was spent is also indicative to what extent China is now driven "from above", almost all the stimulus went to the public sector and local governments (while the main beneficiaries of the Bush-Obama stimulus packages were private enterprises, especially banks and other financial institutions)

\section{Economic performance of "Capitalism from below"}

\section{China, social and economic development ${ }^{3}$}

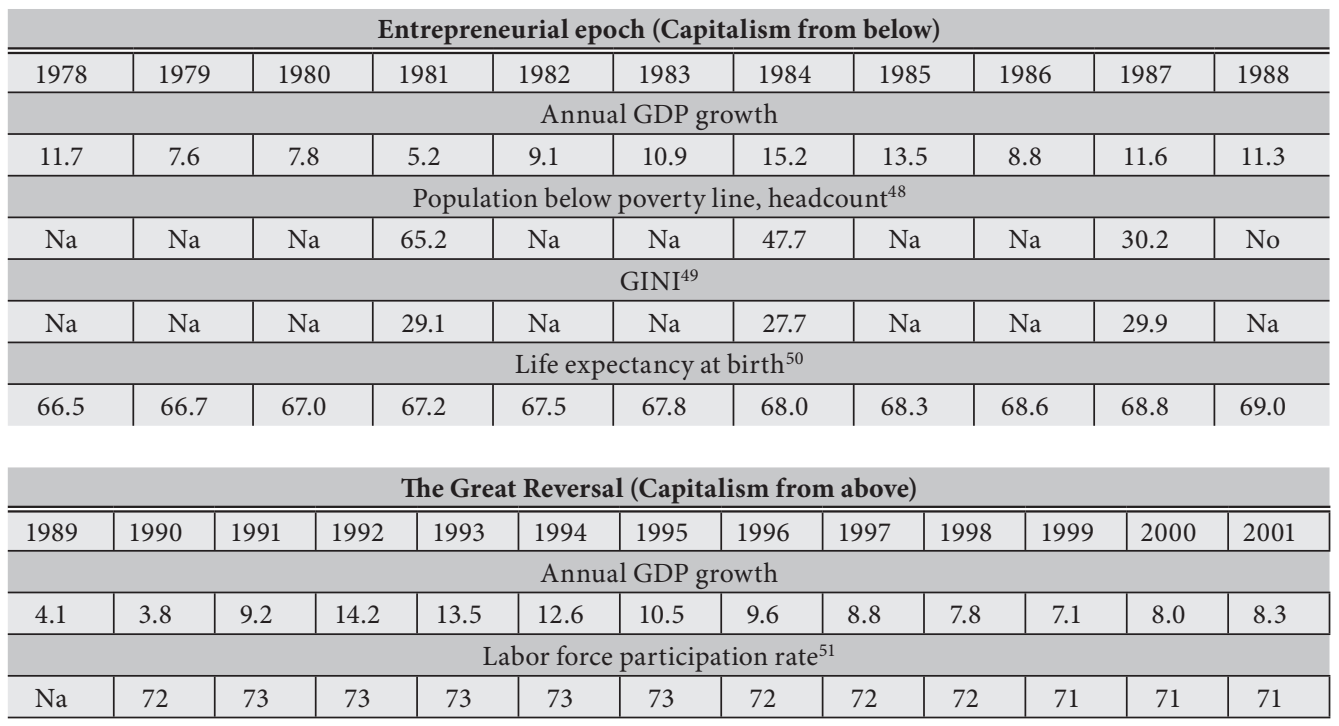

3 National Bureau of Statistics, China statistical yearbooks (http:///www.cinability.com/GDP.htm; CIA World Factbook gives slightly different figures from 1999 


\begin{tabular}{|c|c|c|c|c|c|c|c|c|c|c|c|c|}
\hline \multicolumn{13}{|c|}{ GINI } \\
\hline $\mathrm{Na}$ & 32.4 & $\mathrm{Na}$ & $\mathrm{Na}$ & 35.5 & $\mathrm{Na}$ & $\mathrm{Na}$ & 35.7 & $\mathrm{Na}$ & $\mathrm{Na}$ & 39.2 & & \\
\hline \multicolumn{13}{|c|}{ Population below poverty line, headcount ${ }^{52}$} \\
\hline $\mathrm{Na}$ & 35.0 & $\mathrm{Na}$ & $\mathrm{Na}$ & 30.3 & $\mathrm{Na}$ & $\mathrm{Na}$ & 18.7 & $\mathrm{Na}$ & $\mathrm{Na}$ & 19.9 & $\mathrm{Na}$ & 15.6 \\
\hline \multicolumn{13}{|c|}{ Life expectancy at birth } \\
\hline 69.3 & 69.5 & 69.7 & 69.9 & 70.1 & 70.2 & 70.4 & 70.6 & 70.8 & 70.9 & 71.1 & 71.3 & 71.4 \\
\hline
\end{tabular}

\begin{tabular}{|c|c|c|c|c|c|c|c|c|c|}
\hline \multicolumn{10}{|c|}{ "Social harmony" } \\
\hline 2002 & 2003 & 2004 & 2005 & 2006 & 2007 & 2008 & 2009 & 2010 & 2011 \\
\hline \multicolumn{10}{|c|}{ Annual GDP growth } \\
\hline 9.1 & 10.0 & 10.1 & 9.9 & 11.1 & 11.4 & 9.6 & 8.7 & 10.4 & 9.4 \\
\hline \multicolumn{10}{|c|}{ Labor force participation rate re $^{53}$} \\
\hline 70 & 70 & 70 & 69 & 69 & 69 & 68 & 68 & 68 & $\mathrm{Na}$ \\
\hline \multicolumn{10}{|c|}{ GINI } \\
\hline 42.6 & $\mathrm{Na}$ & $\mathrm{Na}$ & 42.5 & $\mathrm{Na}$ & $\mathrm{Na}$ & $\mathrm{Na}$ & $\mathrm{Na}$ & $47.0^{54}$ & $\mathrm{Na}$ \\
\hline \multicolumn{10}{|c|}{ Unemployment rate ${ }^{55}$} \\
\hline $\mathrm{Na}$ & $\mathrm{Na}$ & 10.1 & 9.8 & 9.0 & 4.2 & 4.0 & 4.3 & $\mathrm{Na}$ & $\mathrm{Na}$ \\
\hline \multicolumn{10}{|c|}{ Public debt (\% of GDP) } \\
\hline $\mathrm{Na}$ & $\mathrm{Na}$ & 31.4 & 24.4 & 22.1 & 18.4 & 16.2 & 16.9 & 17.5 & $\mathrm{Na}$ \\
\hline \multicolumn{10}{|c|}{ Population below poverty line $e^{56}$} \\
\hline $\mathrm{Na}$ & $\mathrm{Na}$ & 10 & $\mathrm{Na}$ & $\mathrm{Na}$ & $\mathrm{Na}$ & 8 & 8 & 2.8 & 2.8 \\
\hline \multicolumn{10}{|c|}{ Life expectancy at birth } \\
\hline 71.6 & 71.8 & 72.0 & 72.2 & 72.4 & 72.6 & 72.8 & 73.1 & 73.3 & $\mathrm{Na}$ \\
\hline
\end{tabular}

When tested against empirical data, Yasheng Huang's theory fares well for the early 1980s, but it does not offer much support to his hypotheses concerning the "social harmony" epoch. Indeed, 1978-1985 produced impressive growth together with a moderation of social inequality. I take this is strong support for Victor Nee's 1989 "market transition theory". But as capitalism shifts from "below" to "above" Nee's theory does not seem to stand any more, but Yasheng Huang's optimistic expectations about a new policy of social harmony, or a social democratic phase of Chinese capitalism or market socialism (you name it the way you want to) does not get much support. Economic growth remains around the same level as it was in the 1990s, but there seem to be no evidence for anymore "social harmony", social inequality reaches its highs at the end of the epoch.

48 Data from Index Mundi, CIA Factbook

49 Data from Index Mundi, CIA Factbook

$50 \%$ of total population ages $15+$, see www.worldbank.org/indicator/SL.TFL.CACT.ZS

51 World Bank estimate, using \$1.08 per day per capita consumption with 1993 PPP, see China from Poor Areas to Poor People. Report No. 37349-CN, March 2009, Washington DC.: The world Bank

$52 \%$ of total population ages $15+$, see www.worldbank.org/indicator/SL.TFL.CACT.ZS

53 CIA World Factbook, 2007. China ranked \#33 among the countries of the world, the US \#41 with a GINI of 45.0

54 Data from Index Mundi, CIA World Fact-book

55 People living below $\$ 1.25$ a day

56 Data from Index Mundi, CIA World Factbook 
Some now regard to $\mathrm{Hu}$-Wen epoch as a "lost decade" and incoming president Xi is expected to open a fourth epoch, with further liberalization of the economy and Singapore like political reform of the party.

Let me offer a few concluding remarks on the case of Vietnam - the case I am the least familiar with and which is also the least covered in scholarly literature. Most commentators I read see Vietnam as following the Chinese strategy of transformation (GuO 2004. 393.; YAMAOKA 2007. 13).

The reform in Vietnam came though substantially later. After the Vietnam War the communist leadership imposed the most doctrinaire policies on the South, creating a major economic crisis and food shortages during the second half of the 1970s (YAMAOKA 2007. 12). The Vietnamese orthodox leadership resisted pressure from reform even when it came from their staunchest ally, the Soviet Union and from Gorbachev - the door to reform only opened up when the arch-conservative Le Duan in 1986 passed away and another conservative, though one with reformist inclinations, Truang took over the leadership (Bunck 1996). The reforms introduced by Truang were called Doi Moi and they resembled in some ways "perestroika" though when the chips came down it was closer to the Chinese rather than the late Soviet and especially early post-soviet Russian model. Vietnam, much like China some seven years earlier, dismantled the agricultural cooperatives and gave agrarian production back to the peasants (this is something Russia never did and the Central European countries did not do either). So in one stroke Vietnam eliminated food shortages and as far as we can tell dramatically reduced poverty during transition (while as we saw poverty skyrocketed in the former USSR and its European satellites). Vietnam also followed China by NOT combining perestroika with glasnost, hence retaining the political monopoly of the Communist Party, what arguably was the precondition - but for a price what many would judge to be unaffordable - of a gradualist transformation (this again is something what distinguished Vietnam and China from the European post-communist regimes - see this point in YAMAOKA 2007. 9.)

Nevertheless, Vietnam's reforms were not only later than the Chinese, they also had more of a shock element. While Vietnam did not rush to mass privatization, it moved more aggressively to market liberalization, shut down early state enterprises, opened faster rooms for the private sector and opened up its borders to FDI (BunCK 1996. 236.). Hence I may argue Vietnamese "capitalism from below" came with a "neo-liberal" flavour. Nevertheless, Vietnam never experienced the transitional recession/depression mainly because in the first stages of reform the rapidly expanding household sector absorbed most of the costs (and labour freed from SOEs - see MCCARTY 2000.)

So far Vietnam is a "success story" - much like China is. They managed the transition without the frightening costs other post-communist transformation trajectories could not avoid. 


\begin{tabular}{|c|c|c|c|c|c|c|c|c|c|c|c|c|c|}
\hline \multicolumn{14}{|c|}{ VIETNAM $^{57}$} \\
\hline 1986 & 1990 & 1995 & 2000 & 2001 & 2002 & 2003 & 2004 & 2005 & 2006 & 2007 & 2008 & 2009 & 2010 \\
\hline \multicolumn{14}{|c|}{ GDP annual growth } \\
\hline 2.8 & 5.1 & 9.5 & 5.5 & 4.7 & 6.0 & 7,2 & 7.7 & 8.5 & 8.2 & 8.5 & 6.2 & 5.3 & 6.8 \\
\hline \multicolumn{14}{|c|}{ Unemployment rate } \\
\hline $\mathrm{Na}$ & $\mathrm{Na}$ & 25.0 & $\mathrm{Na}$ & $\mathrm{Na}$ & $\mathrm{Na}$ & 6.1 & 1.9 & $\mathrm{Na}$ & 2.0 & 4.3 & 4.7 & 6.5 & 2.9 \\
\hline \multicolumn{14}{|c|}{ Labor force participation } \\
\hline $\mathrm{Na}$ & 76 & 75 & 74 & 74 & 74 & 74 & 74 & 74 & 73 & 73 & 73 & 73 & 73 \\
\hline \multicolumn{14}{|c|}{ Population below poverty line } \\
\hline $\mathrm{Na}$ & $\mathrm{Na}$ & $37.0^{58}$ & $\mathrm{Na}$ & $\mathrm{Na}$ & 28.9 & $\mathrm{Na}$ & 19.5 & $\mathrm{Na}$ & $\mathrm{Na}$ & 14.3 & $\mathrm{Na}$ & 12.3 & 10.6 \\
\hline \multicolumn{14}{|c|}{ GINI } \\
\hline $\mathrm{Na}$ & $\mathrm{Na}$ & $36.1^{59}$ & $\mathrm{Na}$ & $\mathrm{Na}$ & $\mathrm{Na}$ & $\mathrm{Na}$ & $\mathrm{Na}$ & $\mathrm{Na}$ & $\mathrm{Na}$ & $\mathrm{Na}$ & 37.6 & $\mathrm{Na}$ & $\mathrm{Na}$ \\
\hline \multicolumn{14}{|c|}{ Life expectancy at birth } \\
\hline $\mathrm{Na}$ & $\mathrm{Na}$ & $\mathrm{Na}$ & 69.3 & 69.6 & 69.9 & 70.1 & 70.4 & 70.6 & 70.9 & 71.1 & 71.3 & 71.6 & 71.9 \\
\hline
\end{tabular}

But both for China and Vietnam the BIG question is - much like for the neo-patrimonial/ rentier states, but for a different reason - sustainability. There are two major reasons why the East Asian transformation from below is vulnerable: (i) will they be able to retain their export led industrialization once the price of their labour will catch up with the rest of the world? (ii) can the political monopoly of the communist party maintained under market capitalist conditions and if it cannot is a "gradualist" transformation of the political system conceivable? If it is not and political systems either stay or fall, what would be the social and economic consequences of such a political disintegration?

Victor Nee in his Capitalism from Below (NeE 2012.) offers us the most optimistic scenario. The main meta-theoretical implication of this formidable book is that the natural or normal way capitalism evolves is "from below". After all, capitalism came also "from below" in England, the United States or the Netherlands. Gershenkron's $19^{\text {th }}$ century cases of finance capital led capitalism in Germany or state-led capitalism in tsarist Russia were aberration just as capitalism by design either in neo-liberal or in neo-patrimonial way may be. Let me add: democracy did not come fast and free. Early capitalism operated sweat-shops, did not have universal suffrage, workers resistance was broken by force. Democracy is a late-comer and came only after strenuous fight for liberty and equality. Hence Jeffrey Sachs may be right (SACHs 2005.): democracy will come to China, but let me add: in due time. Let's not put then wagon ahead of the horse.

But a final word of warning: comparing the various pathways out of state socialism is tricky however. One may just compare apples and oranges. East Asian socialist formation faced very different challenges when reforms began. China during the late 1970s was still an overwhelmingly agrarian society, while before the fall of communism the USSR and its European satellites completed industrialization. China could - and still can - extensively grow and flood the world market with inexpensive industrial goods. The domestic market in China has extraordinary potentials. It is estimated that only about 200 million Chinese from the population of 1.3 billion lives in a mass-consumption society. China in responded to the Global Financial Crisis and the

\footnotetext{
$57 \%$ of total population ages $15+$, see www.worldbank.org/indicator/SL.TFL.CACT.ZS

$58 \quad 1998$

591998
} 
shrinking of world markets for its products by expanding domestic consumption. On the other hand Russia and Central Europe did not have much of a choice. Their political regime melted down in 1989-1991, no room was left for "gradualism", building capitalism "from below" - being integrated into the world system without much or any qualification was inevitable and the crises which followed were logical consequences of such integration.

So can we learn from each other or we only can learn from our own mistakes? I do not want to end this paper with a totally agnostic note. If there is a lesson to be learned it is certainly a complex one.

The road from socialism to capitalism certainly proved to be rockier, costlier (and lasted longer) than anticipated. Some of those costs should be discounted given the "initial conditions", but other costs incurred due to policy choices governments made. Some of the benefits of arriving at the "destination" also might have been overestimated hence popular disillusionment - a common post-communist experience - can be attributed for less benefits than hoped for higher costs than society was prepared to pay.

Let's return to the Irish joke. What could be our response to the stranger somewhere in Ireland lost his way and asks us: which is the best road to Belfast?

First I would ask: Are you sure you want to go to Belfast? There are many other possible destinations why don't you compare at least some of them with Belfast? Would you consider London or Stockholm instead of Belfast? How much do you know about Belfast anyway? Is it possible that Belfast is actually not quite as nice as you think it is so, if you get there you may regret it.

The second point I would make: well, as you should know there are many roads which will get you to Belfast. Some roads may not be for you. Some needs a lot of climbing and given the conditions of your knees, I would not recommend you to take those. But do not allow anybody to fool you and claim: there is only one (or the "best") way you can get to your destination (whatever that may be). So our first task is to eliminate some of the roads which are obviously not suitable for you and once that was done you evaluate carefully what are the costs and benefits of each of the roads open to you.

My final point: each destination offers various kinds of benefits and each road has various, multiple kind of costs. To decide which benefits you want and what costs you are willing to pay cannot be established in a scientific manner, these are political choices a well-informed public needs to make in a democratic process. Belfast is cosy and the beer is good, but the place is boring. London is exciting, but you might find it too big and you would feel lost in it. Stockholm may be of the right size with just enough excitement, but will you stand the long and cold winter nights? So it depends on your preferences what you want. The same goes with costs: if you take road A rather than road B, it may take you longer, but it may be shadier so you will suffer less from exposure to intense sunshine. So how much are you willing to pay from what kind of cost?

After all, with more or less costs, with more or less disillusionment all transitional societies are at some sort of "destination", the "transition" by and large is over. But less illusion, more cool-headed rational calculation by a well-informed public in a democratic discourse may have made this transition less frustrating. And finally, let's not forget: there are no final destinations in history. Market transition is over but there are other transitions (making a welfare state for some, transiting to democratic policy for others or all of the above...) ahead of you. So you are again - always - at cross-roads. Think about the advice we just gave to the lost stranger in Ireland. And do not forget: once you got to Belfast you may continue your journey to London, New York, or who knows, probably to Singapore? 


\section{BIBLIOGRAPHY}

Aslund, Anders (1995): How Russia Became a Market Economy. Washington D.C.: The Brookings Institution

Aslund, Anders (2007): How Capitalism Was Built. Cambridge: Cambridge University Press.

Aslund, Anders -Guriev, Sergei - Kuchins, Andres (eds) (2010): Russia after the Global Economic Crisis. Washington, DC., Peterson Institute for International Economics

Augusztinovics, Maria. 2005. Népesség, foglalkoztatottság, nyugdij (Population, labour force participation and pension), Közgazdasági Szemle, May, pp. 429-447

Baumol, William J, - Litan, Robert E. - Schram, Carl (2007): Good Capitalism, Bad Capitalism. New Haven, CT.: Yale University Press

Behlami, Hazem - Giacomo Lucsiani (eds) (1987): The Rentier State. London, Croom Helms

Berend, Ivan T. (1998): Central and Eastern Europe. Detour from the Periphery to the Periphery. Cambridge, Cambridge University Press

Bradsher, Keith (2009): In Downturn China Sees Path to Growth. The New York Times, March 16.

BunCK, Julie M. (1996): Marxism and the Market: Vietnam and Cuba in Transition. Proceedings of the Annual Meetings of the Association for the Study of Cuban Economy (ASCE)

China from Poor Areas to Poor People (2009): Report No. 47349-CN. Washington DC., The World Bank Davidson, Christopher (2005): The United Arab Emirates - a Study of Survival. London, Lynne Riemer. Davidson, Christopher (2009): Abu Dhabi - Oil and Beyond. New York, Columbia University Press.

Dragutinovic-Mitrovic, Radmila - Ivancev, Olgica (2010): Driving forces of economic growth in the second decade of transition. Economic Annals vol. 55. no. 185. 7-32.

EEAD.2012.The EEAG Report on the European Economy, Munich: CESifo

European Bank for Reconstruction and Development.2000. Transition Report 1999. Ten Years of Transition. London: EBRD

European Bank for Reconstruction and Development. 2012. Regional Economic Prospects in EBRD Countries of Operations: May 2012 www.ebrd.com

Eyal, Gil - Szelenyi, Ivan - Towsley, Eleanor (1998): Making Capitalism without Capitalists. London, Verso

Gershenkron, Alexander (1962): Economic Backwardness in Historical Perspective. Cambridge, MA., Harvard University Press.

Guo, Sujian (2004): Economic Transition in China and Vietnam. Asian Profile vol. 32. no. 5. 393-411.

Hamm, Patrick - King, Larry - David Stuckler (2012): Mass Privatization, State Capacity, and Economic Growth in Post-Communist Societies. American Sociological Review vol. 77. no. 2. 295-324.

Herbertsson, Tryggvi Thor - Orszag, Mike (2003): The Early Retirement Burden. Watson Wyatt Technical Reports, Report 2003-LS04

Huang, Philip (2012): Profit-Making State Firms and China's Development Experience - State Capitalism or Socialist Market Economy? Forthcoming in Modern China.

HuAng, Yasheng (2008): Capitalism with Chinese Characteristics. Cambridge, Cambridge University Press.

Hungarian Central Statistical Office. 1997. Mikrocenzus 1996. Budapest: KSH

Kadochnikov, Pavel (2006): An analysis of Import Substitution in Russia After the Crisis of 1998. Problems of Economic Transition vol. 49. no. 6. 5-103.

King, Lawrence (2003): Shock Privatization: The Effects of Rapid and Large Scale Privatization on Enterprise Restructuring. Politics and Society vol. 31. no. 1.3-30.

King, Lawrence - Ivan Szelenyi (2005): Post-Communist Economic System. In Smelser, Neil -Swedberg, Richard (eds.): The Handbook of Economic Sociology. Princeton University Press. 205-229.

Klebnikov, Paul (2000): Godfather of the Kremlin. New York, Harcourt.

KLIGMAN, GAIL - Szelenyi, Ivan (in collaboration with Christy Glass and Janette Kawachi) (2002): Poverty and Social Structure in Transitional Societies. New Haven, Yale University, Center for Comparative Research. Unpublished book manuscripts. 
Kolosi, TAmÁs - RoBert, PÉTER (2004): A magyar társadalom szerkezeti átalakulásának és mobilitásának fö folyamatai a rendszerváltás óta. (Changes in Hungarian social stratification and mobility since the fall of communism) Társadalmi Riport. Budapest, TARKI. 48-74.

KornaI, JÁnos (1980): Economics of Shortage. Amsterdam: North Holland.

KornaI, JÁnos (1984): Bureaucratic and Market Coordination. Osteurope-Wirtschaft vol. 29. no. 4. 306-319.

KornaI, János (1992): The Socialist System. Princeton, Princeton University Press.

Kornai, János (2008): From Socialism to Capitalism. Budapest, Central European Press.

Kornai, JÁnos - Maskin, Eric - Roland, Gerard (2003): Understanding Soft Budget Constraints. Journal of Economic Literature vol. 41. no. 4. 1095-1136.

Kuru, Ahmet (2002): The rentier state model and Central Asian Studies: the Turkmen Case. Alternatives vol. 1. no. 1. 51-71.

LAdÁNYI, JÁnos (2012): Leselejtezettek. Budapest, L’Harmattan Kiadó.

Mahdavy, Hussein 1970: "The Patterns and Problems of Economkic Development in Rentier States" in M.A. Cook (ed).Studies in Economic History of the Middle East. London: Oxford University Press

McCarty, Adam (2000): The Social Consequences of Economic Transition in Vietnam. www. mekongeconomics.com

Nee, Victor (1988): A Theory of Market Transition. American Sociological Review vol. 54. no. 5. 663-681.

Nee, Victor - Opper, Sonja (2012): Capitalism From Below. Cambridge, MA, Harvard University Press.

OI, JeAn (1992): Fiscal Reform and the Economic Foundations of Local State Corporatism in China. World Politics vol. 45. no. 1. 99-126.

OI, Jean (1999): Rural China Take Off. Institutional Foundation of Economic Reform. Berkeley, University of California Press.

Peternelj, Mateja (2005): Slow is beautiful? Slovenia's approach to transition. ECFIN Country Focus vol. 2 no. 10.

Ross, Michael L. (1999): The Political Economy of Resource Curse. World Politics vol. 51. no. 2. (January) 297-322.

Rutland, Peter (No date): Can Russia Escape the Oil Curse? Wesleyan University (working paper) www.pratland.wesleyan.edu/documents/resource\%20curse.pdf

Sachs, Jefrerey 2005. The End of Poverty. New York, Penguin Press.

Sidosenko, Alexei (2011): Avoiding the Resource Curse in Russia. Mission Impossible? Future Challenges BertelsmannStirftung, 15 th June 2011.

StARK, David (1996): Recombinant Property in East European Capitalism. American Journal of Sociology vol. 101. no. 4. 993-1027.

STIGLiTZ, JosePh (2003): Globalization and Its Discontents. New York, W.W. Norton.

Stuckler, David - Lawrence King - Martin McKee (2009): Mass privatization and the post communist mortality crisis. www.thelancet January 15, 2009

ŠUŠTERŠIČ, J. (2004): Political economy of Slovenia’s transition. In Mrak, M. - Rojec, M. - Silva-Jáuregui, C. (eds): Slovenia - From Yugoslavia to the European Union. Washington D.C., The World Bank. 399-411.

Szelenyi, Ivan (1978): Social Inequalities in State Socialist Redistributive Economies. International Journal of Comparative Sociology vol. 19. no. 1-2.63-87.

Treisman, Daniel (2010): Rethinking Russia. Is Russia cursed by Oil? Journal of International Affairs vol. 63. no. 2. 85-102.

Vidmar, Andreja Kavar (2000): Social Exclusion and Poverty in Slovenia. Brussels, Observatoire Social Europeen.

Yамаока, Kana Ko (2007): Comparison of Two Remaining Socialist Countries - Cuba and Vietnam. Harvard University, USJP Working paper 07-15. 